\title{
Social Entrepreneurship as One of the Business Development Activities in Rural Areas of Latvia
}

\author{
Ms Silva Jeromanova -Maura \\ Turiba University, \\ Riga, Latvia \\ silva@silja.biz
}

Abstract Since 1 of April 2018, it is possible to register social entrepreneurship in Latvia as one of the type of business and to take advantage that is only suitable for this type of business.

The study analyses how coud social entrepreneurship become one of the opportunities to address social problems, directly in rural areas, where today in Latvia is concentrated the largest population of a socially unprotected groups.

This means that, while developing social enterprises and solving social problems in the regions of Latvia, at the same time, also address other issues that are actual today - lack of labour force.

For entrepreneurs in rural areas, the lack of labour is the most significant, and there is no problem in Latvian regions with finding a place of residence. The development of social entrepreneurship would also be a contributory factor in the fact that the new generation would not leave the countryside, but try to build up their business using existing infrastructure, including a rural school, kindergarten - it helps to them continue to work as well.

In the Latvian countryside most are farmers and crafts companies, whose business is most often expressed seasonality. At the rural areas farmers can support with works during sowing and harvesting, and some works during growing period on organic farms.

There is also a growing lack of labour force in the sales companies who support farmers with new technologies, especially in aftersales - service departments.

Social entrepreneurship could be one of the solutions, especially since it is very seasonal for repairs, so that it is possible to focus the work on the season by successfully management with the contingent in the countryside.

There is a great opportunities to make cooperation with local authorities on this issue, the role of the social business in the development and social Affairs of the rural environment should be clarified. As a result of successful cooperation, social enterprises can become an important contribution to local authorities in addressing the societal challenges of the municipality.

The study analyses how important to develop this model of cooperation, as it needs to convince local leaders before work on regional reform begins.

Keywords - social enterprise, social entrepreneurship, regional reform, rural development.

\author{
Mr. Ilmārs Šukjurovs \\ Turiba University, \\ Riga, Lavia \\ ilmars@eventagency.lv
}

\section{INTRODUCTION}

The growth of modern economic systems has generated more numerous, complex and urgent social challenges. [2]

Despite the social innovation being defined and interpreted differently, it provides the social benefits for both local community and/or society in general.

Nowadays, social innovations, particularly in the rural areas, focus on successful solution of different social, economic, political and environmental issues. The social benefits, for instance, reduce the threat of climate change ,maintain the biodiversity, ecosystems and landscapes; offer fresh and healthy local food etc., can be provided by the social innovations based on the agricultural production and other rural activities.

The following social innovations (but not all) will be suitable for Latvia:

- sustainable or environment friendly agricultural production;

- local food systems

- social or care farming,

- $\quad$ social services;

- renewables (e.g. bioenergy);

- ecosystem services (ecotourism) and recreation services;

- cooperation;

- local action groups and financial services. [1] [5] [8]

As a result of technological advances and capital gains, the volume of economic performance generated by the same amount of work-related resources increases from one year to the year. Technological developments are mainly aimed at reducing work resources in the farming process. For one of the most popular politicians slogans have become "Create new jobs".

In fact- this is wrong, because not a number of jobs, but the result /productivity of work would be important in terms of prosperity. [2]

Technological developments lead to two-fold effects on the rural economy - on the one hand reducing the number of workers needed for entrepreneurs - and, on the other hand, the need for more and more young, welleducated, new-knowledge workers.

It is basically new people - new families who are ready to move to the countryside only if they are equipped with the appropriate infrastructure - living conditions, roads, kindergartens, schools, social services, cultural life.

The countryside, nature are Latvian identity and the

Print ISSN 1691-5402

Online ISSN 2256-070X

http://dx.doi.org/10.17770/etr2019vol1.4165

(C) 2019 Silva Jeromanova-Maura, Ilmārs Šukjurovs Published by Rezekne Academy of Technologies.

This is an open access article under the Creative Commons Attribution 4.0 International License. 
future of Latvia. For young people it is serious choice to find themselves in Latvia or to go to another country, when they choose the fields of education, business or make a more serious choice - to leave from native country.

They must first understand whether they can work- in fast food shops, greenhouses, hotels or other low-skilled jobs abroad, in Riga - or to build up their professional life in the countryside of Latvia.

Developing the rural economy is one of the key indicators towards a country's success. Whether it be the need to look after the welfare of the farmers or invest in rural infrastructure. Best way how to improve life in countryside - is to look at "people's participation".

Social entrepreneurship is the ability to draw in innovative solutions by businesses to solve different social problems. From a rural development point of view, social entrepreneurs can work to fill the societal gap, helping in social transformation of the economy.[1]

With planned and innovative attempts, Latvia can work towards combating problems like poverty, inequality, unemployment in countryside. The benefits are double ended - social entrepreneurs can look forward to making profits while the society gains at large.

The problem needs to be addressed both from employees, workers and the public and local authorities, this is a matter of complexity, one of the most important choices, projects and decisions before the Latvian countryside are completely empty, before the schools and nurseries are closed.

It is only through cooperation, with the help of variety of laws and projects, including those European Union funds support, to change the situation in Latvia. This is a question that is often debated, but fully in a systematic, coordinated way, with all the interested parties working together, still not resolved.

From time to time there are some very valuable activities on these issues, but they are usually impulsive without any results in the long term. A social entrepreneurship would be one way for entrepreneurs to develop their business in rural areas, in cooperation with local authorities, in the development of their businesses, while helping the municipality address the social issues with which they are not to be able handle to end, what is one of the reasons that people leave the countryside, thus creating even greater challenges for entrepreneurs to find the necessary staff.

Social enterprises solve problems faced by not one or two people but larger sections of society. These are problems which, suffered by the general public in the long term and have not been solved from state or business sector or non-governmental organisations. [5]

At the end all will have benefits, in addition to have savings in national /state and municipalities budgets, as social enterprises often remove different types of social helps from shoulders of municipalities.

To calculate benefits, we must put an account not only tax income from social enterprises, but also decreasing of costs for social support. [8]

It is often social entrepreneurs, as much as traditional entrepreneurs, who are involved in developing new ideas, new products and activities, and envisioning a future for the rural area.

For young people to find themselves in Latvia or to go to another country if they choose the fields of education, business or make a more serious choice, you must first understand whether you can work in fast food shops, greenhouses, hotels or other low-skilled jobs abroad, in Riga - or to build up their professional life in the countryside of Latvia.

One of very important findings of paper - the problem needs to be addressed both from employees, workers and the public and local authorities, this is a matter of complexity, one of the most pressing at the moment, before the Latvian countryside are completely empty, before the schools and nurseries are closed. It is only through cooperation, with the help of a variety of laws and projects, including European Union funds - financial support, is possible to change the situation .

This is a question that is often debated, but fully in a systematic, coordinated way, with all the interested parties working together, still not resolved. From time to time there are some very valuable activities on these issues, but they are usually impulsive without any results in the long term.

A social entrepreneurship would be one way for entrepreneurs to develop their business in rural areas, in cooperation with local authorities, in the development of their businesses, while helping the municipality address the social issues with which they haven't been able to handle, which is one of the reasons that people leave the countryside, thus creating even greater challenges for entrepreneurs to find the necessary staff. [8]

Social enterprises solve problems faced by not one or two people but larger sections of society. These are problems which, in essence, are suffered by the general public in the long term and have not been solved by state or business sector or non-governmental organisations. [5]

At the end all will have benefits, in addition saving the money for national /state and municipalities budgets, as social enterprises often remove different types of expenditures from the state and municipality, helping to make more effective use of taxpayers ' money over the long term.

Perhaps someone who has long dreamed of being a business can finally implement it through local government and state aid, as well as tax relief.

Social enterprises can operate in a wide range of business areas-the main thing that there is a clear social objective, both an activity sector and a business model.

Of course, the logic of the social enterprise should be excluded obviously the harmful sectors-weapons, cigarettes, drugs, etc. [3] [4]

The new social company Law also mentions a number of other sectors in which social enterprises in Latvia cannot function, but it is more in Latvia's local context than conceptual considerations. A social enterprise can just as well operate in the timber industry, as in food production, as a video hardware rental business, as long as there is a clearly identifiable social objective and positive social impact that the company generates through its work. It can certainly be said that social entrepreneurship 
is a future business, as it is already in Europe and in the world, the smarter heads of the big business are looking for new and new social enterprises in different business areas - they involved wide sections of the population.

Investors increasingly also require a strong social impact aspect of traditional businesses, as well as big brands increasingly thinking about how the social impact aspect is to be realised not only by certain charitable form of projects, but in all activities and business processes that take place on a daily basis. [5] [8]

Also in Latvia we see that there is growing interest in both business and customer and consumer, it is increasingly important that not only to rake in money, but we can do something good at the same time, and not only one or two times, but in the long term.

Another element of the high level and potential of the Latvian rural activities is the low scale of the country and borders with its neighbours, Estonia (the road to Finland), direct links with Sweden (ferry to Stockholm), Lithuania, Poland, while the largest advantages is border with Post Soviet countries as Belarus, Ukraine, as well Russia, -there is a big market and our mentalities are very similar. [8]

\section{RESULTS AND DISCUSSION}

In the last twenty years, the business activity in Latvia has evolved very rapidly, big part of the large and successful enterprises mostly located in the big cities, leaving the countryside empty. [1]

In turn, social problems are left to the discretion of the state and local authorities, partly addressing these issues to non-governmental organizations.

In order to investigate the situation, the most valuable information could be obtained in interviews with the authorities in rural regions, entrepreneurs with long experience in business, especially in countryside, with the professional management of technical schools, municipal leaders, social entrepreneurs, Ministry of wellfare, officials and social partners of Ministry of Economy, Chamber of Commerce, leaders of the nongovernmental organizations.

By listening to the various perspectives on the developing process of the social entrepreneurship, the law of Social Entrepreneurship, the need for justification and its implementation in life, as well as an understanding of the impact of social entrepreneurship on rural regional and its place of business, you can do Conclusions, conduct a SWOT analysis and predict the sustainability of social entrepreneurship in regions of Latvia.

The countryside in Latvia remains one of the most ecologically clean environments in Europe, which could become a prerequisite not only for new families in Latvia, but also for new families from other European countries to consider creating their business in the countryside of Latvia.

In addition, a variety of financial instruments of the European Union are still available to help to start a new business, to expand an existing business, and to acquire good quality; additional Education -needed to to every entrepreneur for successful business development.

To respect the diversity of generations, more and more workers are choosing a freelancer type of work, when you can organize your work every time, day, month by yourself. More and more people choose to work from home, which means that rural areas do not need to develop business centers and officies, as previous years, to have a small demand for coworking spaces. It means not need to make investment for premises. [8]

As one of the prospective activities, there is a social enterprise which may become an existing or newly established company, an existing non-governmental organization or association. The status of a social enterprise can be obtained by companies with limited liability, pursuing a creative economic activity with a positive social impact, such as providing social services, forming an inclusive civil society, promoting education, supporting Environmental protection and conservation, ensure the protection of animals or promote cultural diversity. [4]

If we look at industries, there are many different options in Latvian countryside: Fisheries, Forestry, non-agricultural production, services, tourism smallscale food processing, domestic production, social entrepreneurship, etc.

Fisheries: fishing, the cultivation of goods by order, In the use of a pawing of fish stocks, offering farmed fish for fishing in ponds. The pond is a sector that requires a large capital investment, but is a perspective, because it is possible to unite it with tourism, meaning two businesses in one principle. [8]

Forestry : is one of the main business types in Latvia, $45 \%$ of Latvian territory is occupied by forests. The Latvian forests have a unique biological diversity. Per capita, Latvia has 1.1 hectares of forest, which ranks fourth in Europe in this index. [1]

Non-agricultural production: continuing forestry business opportunities include woodchip production, one of the most important export products, as well as furniture production, wood production. The Latvian countryside also contains a number of successful sweets producers, clothing etc.

Toy makers, textile manufacturers, manufacturers of various fashion accessories.

One of the important directions for Latvian rural producers is not only production of honey and honey products, but also a variety of treatments and cosmetic products, or their raw materials, not only for the local market, but also for export - soap, tea, herbal teas, masks, creams, treatments.

Services - The development of rural activities, the situation where new families move to live, or, on the contrary, to keep the young generation in the countryside, it is necessary to develop a variety of services that meet today's standards, requirements and the new generation Interests. [8]

Traditions of previous generations - choirs, ensembles, dancing groups are much too less for the younger generation to be interesting to live in the countryside.

Wellness is one of the services that has been requested, which has not been typical for previous generations, as well as sporting activities - gyms, pools, slobs, accountancy and consultancy services, legal 
services, IT services and Other modern lifestyles require service types.

Existing services need to be developed in the quality of modern technologies and standards of life, for example, it is necessary to invest in knowledge as well as service equipment.

Many services, including trade, can be carried out remotely, especially the young generation is more likely to have purchased by websites than in shops.

Tourism -A wide range of tourism is available in rural areas, and the basic rule is nature and infrastructure. The main pre-requisites for tourism development is the geographical location.

A rich cultural historical heritage - the different peoples of the world have gone across Latvia, German landlord famous hunting, summer castles still present and many have been refurbished in recent years.

Resort traditions - especially for neighbours from eastern countries, former post Soviet countries - Latvian resorts are popular for them - climate, mentality and language skills.

Reduced nature - still in many places a completely unbroken nature with a natural flora and fauna characteristic for the environment.

Small-scale food processing - Small farms, home manufacturers are able to produce very special unique originals in small quantities with a specific taste-rich food, which realize at larger or smaller trade fairs, whether in their own region or in the big towns and in the Riga market. There is already a popular celebration of different cities, where small producers are actively trading,

Christmas time is an opportunity for these small producers to earn. Traditionally, in particular, local businesses, in cooperation with small producers, produce a wide variety of unique products - which, through their own logo, are complemented by entrepreneurs and donates to their customers and business partners.

Domestic production is always the perfect option for a small but well-performing business, which can be developed and expanded over time.

Social entrepreneurship -is one of the types of business that can be developed in rural areas, in cooperation with local authorities, to address the problems with which the local authority has not been able to cope, while maintaining a living countryside with the necessary services providing other Who find work in local businesses.

Social entrepreneurship essentially includes both business and social and charity different elements, and profits earned are invested in achieving social goals.[5]

Although certain support mechanisms and a few financial instruments for social innovation and employment exist in practice, they are not specifically designed and adapted to the development or support of the social business environment, directly for social enterprises and Development. The concept is intended for the Cabinet of Ministers to identify the priorities to be supported, both in terms of societal challenges and in the support of problem groups. [3]

In a Latvian situation the social enterprise will follow Commercial law An entity (commercial company) that, based on a legal set of criteria, will be assigned a specific social status in a legal order.[3]

Good examples of social entrepreneurship are:

Wooly World - which produces quality natural material for toys, mostly for export. There are blind and partially-sighted workers working in the production of felt bears.

Mammu Ltd - produces high quality and very expensive scarves for export (one scarf cost $70-150$ EUR). The scarves produce young mothers, regardless of their place of residence, and also take into account the fact that young mothers are not able to work full time in the first year of a child.

Juhu Ltd - produces porcelain and ceramics, with individual designs, producers are people with special needs.[5]

Next to these already smart examples, author want to put the opportunity in rural areas, by establishing new homes for old-people - care centers, which will be increasingly demanding in the modern life age, in Latvian society is not popular lifestyle to live under one roof several generations. Children are no longer ready and they are not able to take care of their parents and grandparents because of the rapid rhythm of their lives. [5] [8]

This is why it is necessary to first break the stereotype of care centers, such as alms -house, poorhouses, and to form social entrepreneurship in rural areas. This would make it possible to find new jobs for a large number of rural populations, in addition to the elderly who have trouble finding a job not only because of their age, but also very poor skills and education.

It is very important to find a wide range of ways to employ, to engage the new generation in the labour market, since large funds have been invested in their education, there is a lot of investment in rural schools - especially colleges (technical schools, professional engineering Branches in rural areas.

It would be irresponsible in the near future to have these schools closed down due to the number of students or to let young people with good education to leave Latvia and go to earn money and pay taxes in other countries, at the same time companies in Latvia will reduce their activity because they haven't enough workers, especially educated specialists.

Currently in Latvia, young people have access to vocational training in 12 educational establishments which prepare specialists for various sectors for which the rural environment is more appropriate.

For example, Kandava State agriculture Technical school prepares mechanics for horticulture, Bulduru Agriculture School of gardening - Agronoms, gardeners, landscape architects,

Ogre State technical school - Prepares Woodmen,

Malnavas College, Saulaines Professional Secondary school, East Latgale Vocational School, Smiltene technicaly school, National Priekuļi agricultural technical school, etc.

Besides educational opportunities, the various financial instruments still available for business development, including social entrepreneurship development, are a good prerequisite and the opportunity to create social entrepreneurship as one of Businesses, which at the same time address not only social problems, 
providing local authorities, promoting labour supply to rural entrepreneurs but developing existing ones and enabling new start-ups in rural areas; Taking into account the request.

Support for the start-up and development of new enterprises, including social enterprises, may be provided: 1. Municipalities (Business ideas will get financial support, rent of premises for symbolic payment, business consultants for free, The right of state and local authority to grant certain relief and support - the right to give (donate) movable property, to grant real estate tax rebates, to transfer to the non-refundable use of the property. [3] [4] [5]

2. Bank projects, small business schools, soft loans, preferential arrangements,

3. Altum programmes,

4. Erasmus + covers all existing schemes in the fields of education, development, Youth and Sport (Erasmus, Leonardo da Vinci, Comenius, Gruntvig, Erasmus for Young Entrepreneurs etc.)

5. Association of Private Investor of Latvia (www. biznesaengeli.lv)

6. Ideas contests, Projects (Bridge IT, Solis, Atsperiens, Pumpurs, etc.)

7. Kickstarter-a business idea web platform.

Social entrepreneurship also includes support or benefits in the field of taxation in order to promote the creation and development of such enterprises. The draft law obliges social enterprises to Support measures. This status acquired by an enterprise may not include in the corporate tax base a range of costs, such as the cost of measures for the rehabilitation and social inclusion of workers, Expenditure on the integration of persons into the labour market, the acquisition of assets that serve the purposes of the statutes, as well as donations for public benefit purpose entities. [4]

In the light of the above facts, while hearing the views of experts from business, local authorities and social Entrepreneurship, Author take the SWOT analysis of the social enterprise in terms of social entrepreneurship as one of the forms of social entrepreneurship in the rural are.

TABLE 1 (SWOT ANALYSE)

\begin{tabular}{|l|l|}
\hline \multicolumn{1}{|c|}{ Strenghts } & \multicolumn{1}{c|}{ Weaknesses } \\
\hline $\begin{array}{l}\text { A new business niche, } \\
\text { State and municipal sup- } \\
\text { port, } \\
\text { Finansial support from } \\
\text { EU, } \\
\text { Tax incentives }\end{array}$ & $\begin{array}{l}\text { Little and controversial in- } \\
\text { formation, } \\
\text { Stereotype - people with } \\
\text { special needs } \\
\text { There are not many enter- } \\
\text { preneurs who are socially } \\
\text { responsible } \\
\text { No profit for owners }\end{array}$ \\
\hline \multicolumn{1}{|c|}{ Opportunities } & \multicolumn{1}{|c|}{ Threats } \\
Cross-border cooperation \\
$\begin{array}{l}\text { Social Enterprise-subsid- } \\
\text { iary for traditional LTD, to } \\
\text { fulfil the socially responsi- } \\
\text { ble business function } \\
\text { Sufficient workforce }\end{array}$
\end{tabular} \begin{tabular}{l}
$\begin{array}{l}\text { Inability to earn for to sus- } \\
\text { tain economic activity } \\
\text { The change of the laws } \\
\text { (non-long-term support } \\
\text { agreement) }\end{array}$ \\
\hline
\end{tabular}

Links between social innovation and social entrepreneurship

TABLE 2 (LiNKS BETWEEN SOCIAL INNOVATION AND SOCIAL ENTREPRENEURSHIP)

\begin{tabular}{|l|l|}
\hline Social innovations & Social entrepreneurship \\
\hline $\begin{array}{l}\text { New solutions to social } \\
\text { challenges }\end{array}$ & $\begin{array}{l}\text { New responses to social } \\
\text { challenges. }\end{array}$ \\
\hline $\begin{array}{l}\text { Improvement of individual } \\
\text { and collective well being } \\
\text { and quality of life }\end{array}$ & $\begin{array}{l}\text { Explicit pursuit of positive } \\
\text { externalities. }\end{array}$ \\
\hline $\begin{array}{l}\text { Conceptual, process } \\
\text { or product change, } \\
\text { organisational change and } \\
\text { changes in financing, and } \\
\text { new relationships with } \\
\text { stakeholders and territories }\end{array}$ & $\begin{array}{l}\text { New forms of internal and } \\
\text { external governance. }\end{array}$ \\
\hline \multicolumn{1}{c}{ Changes in financing } & $\begin{array}{l}\text { Mixed financing (public, } \\
\text { private, monetary and not } \\
\text { monetary). }\end{array}$ \\
\hline $\begin{array}{l}\text { Changes in relationships } \\
\text { with territories }\end{array}$ & Strong links with territories. \\
\hline
\end{tabular}

\section{CONCLUSIONS}

The idea of social entrepreneurs helping shape the rural economy isn't new.

Social entrepreneurship is one of the business opportunities in rural areas, which is well-managed and organized can make a big contribution not only to the region, but also to the economy of the country.

The various roles of social entrepreneurs within rural destination development are explored.

Addressing social problems in regions by taking over a fraction of the social problems within the remit of national and local authorities, while providing support to other entrepreneurs in the regions, helping to keep Labour in the regions of Latvia. Special attention is paid to young people, who have learned education in a wide range of professional technical schools, with high-quality specialists in the countryside, which are not intended to meet the rural environment. This could also prevent the closure of training institutions with large financial resources in the future, due to the lack of learners.

The social companies that are already operating in Latvia have been successful in the way they have proven and need much more to tell them, to share their experiences, to encourage others to embark on social work.

There are many different types of business sectors that are able to build successful social entrepreneurship without fear of raw materials or shortages.

Close cooperation between national, municipal and economic operators is necessary to improve the situation and to realize the plan. Some of the same questions received from the different institution are often contradictory.

It is necessary to tell, explain, advise, and refer about social enterprises not only the entrepreneurs and representatives of nongovernmental organizations, but also leaders of municipalities and whole Society. There are often stereotypes about who are social enterprises and who are people with a special needs. 
In the future, social enterprises should be built on the base of traditional companies, so that any socially responsible company will fill their functions, when a new tax law, valid from January 2018, is not favorable for donation and socially responsible events.

As one of the risks of a social business for successful development, Author can mention the desire to share the profit for owners when a social enterprise is the only source of income for the entrepreneur. In the long term it cannot be interesting for young entrepreneurs.

Entrepreneurship can have social results, intended (by what are often called social entrepreneurs) but also unintended (when a business idea leads to social change) or maybe partially-intended; moreover, new ideas, new products, or new services, may turn out to be social innovations regardless of any social impact intended by the inventor,

The potential of social entrepreneurs to engage in rural development is huge. Rural areas are often the perfect places for renewable energy facilities to be located, which translates to increased employment opportunities for the local public as well.

Social entrepreneurs can aid in developing a sustainable business development model while finding the right opportunities unique to the local needs. This also helps the country focus more on $\mathrm{R} \& \mathrm{D}$, and innovations in the rural economy translate to increased development progress.

\section{REFERENCES}

[1] Summary of the concept of "social entrepreneurship introduction in Latvia" (MK noteikumi 30 October 2014 rīkojums Nr. 618)

[2] The Law of Social Enterprise.2017.

[3] What are the social business opportunities in Latvia? Interview with the Association Ex Manager Madara Ulande 2018

[4] Social innovation and its types in rural areas Ligita Melece, Droec. +, 1 Latvian State Institute of Agrarian Economics (2015. April 23. -24)

[5] Noya, A. (2011). Social Innovation: Improving Individual and Collective Well Being. http://efi2011.eai.eu/sites/default/files/ documents/30november/NOYA_fin.pdf. Access: 3.01.2015.

[6] Interview with experts from different business areas in regions of Latvia - social entrepreneurship in rural area. 2018./2019. 